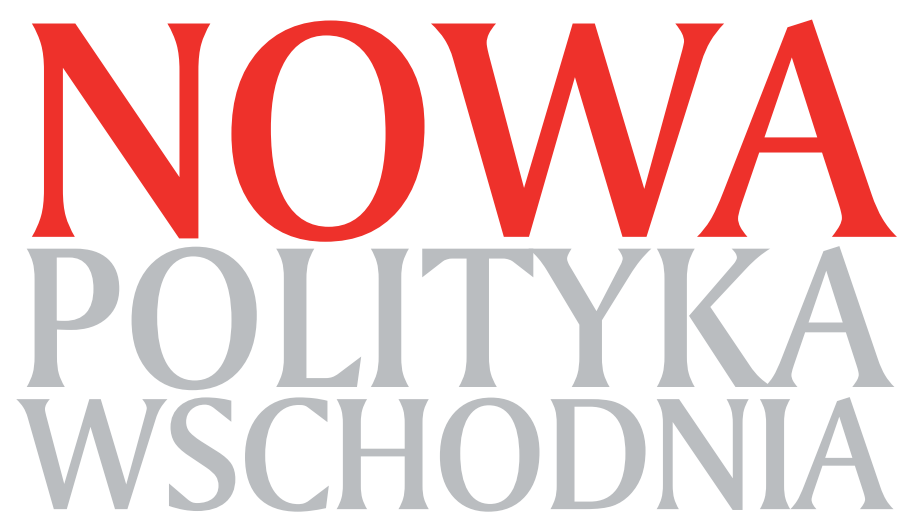

ISSN 2084-3291

2018, nr 3 (18) 


\title{
NOWA POLITYKA WSCHODNIA
}

\author{
RADA NAUKOWA \\ Joanna Marszałek-Kawa (REDAKTOR NACZELNY) \\ Nurlana Aliyeva, Daulet Baideldinov (ZAstęPCy RedaKtora naCZelnego) \\ Tadeusz Bodio (PRZEWODNICZĄCY RADY NAUKOWEJ)
}

Vahit Akayev (Rosja), Natalia Antonyuk (Ukraina), Roswitha Badry (Niemcy), Walenty Baluk (Polska), Viktor Chernous (Rosja), Manereliin Chimedtseye (Mongolia), Brook Colley (USA), Ozgur Unal Eris (Turcja), Sylwester Gardocki (Polska), Mikhail Ilyin (Rosja), Grzegorz Janusz (Polska), Paweł Jessa (Białoruś), Nino Kemertelidze (Gruzja), Wojciech Materski (Polska), Sean McEnroe (USA), Eugeniusz Mironowicz (Polska), Yves Morin (Francja), Rafig Manaf Novruzov (Azerbejdżan), Jaroslav Pánek (Czechy), Ahmet Renima (Algieria), Akmal Saidov (Uzbekistan), Uladzimir Snapkouski (Białoruś), Jacek Sobczak (Polska), Alicja Stępień-Kuczyńska (Polska), Konrad W. Studnicki-Gizbert (Kanada), Kim Sueng-li (Korea Pd.), Mariusz Wołos (Polska), Precious Yamaguchi (USA), Yuksel (Alper Ecevit (Turcja), Igor Zhukovskiy (Rosja), Arkadiusz Żukowski (Polska)

\section{REDAKTORZY DZIAÆÓW}

Zbigniew Girzyński - historia, Rafał Glajcar - polityka, Krystyna Gomółka - migracje, edukacja i współpraca gospodarcza, Adam Hołub - bezpieczeństwo, Zbigniew Karpus - stosunki międzynarodowe, Krystyna Leszczyńska - kultura i społeczeństwo

SEKRETARZE CZASOPISMA

Ualikhan Akhatov, Khalida Babashova, Michał Dahl, Antonina Kozyrska, Anna Ratke-Majewska

\section{ZESPÓÆ REDAKCYJNY}

Judyta Bielanowska, Izabela Borucińska-Dereszkiewicz, Natalia Gburzyńska, Błażej Jewartowski, Justyna Lubańska-Gómez, Justyna Maguś, Magdalena Murszewska, Joanna Piórkowska, Patrycja Rutkowska, Katarzyna Sopolińska, Łukasz Wielgosz, Ilyas Hamidov

$$
\begin{gathered}
\text { REDAKTOR PROWADZACY: Daniel Kawa } \\
\text { REDAKTOR TECHNICZNY: DYWIZ } \\
\text { KOREKTA: Zespół } \\
\text { PROJEKT OKEADKI: Kamil Majewski } \\
\text { (C) Copyright by Towarzystwo Azji i Pacyfiku } \\
\text { (C) Copyright by Centrum Badań Wschodnich } \\
\text { (c) Copyright by Wydawnictwo Adam Marszałek }
\end{gathered}
$$

Wszystkie prawa zastrzeżone. Książka, którą nabyłeś, jest dziełem twórcy i wydawcy. Żadna jej część nie może być reprodukowana jakimkolwiek sposobem - mechanicznie, elektronicznie, drogą fotokopii itp. - bez pisemnego zezwolenia wydawcy. Jeśli cytujesz fragmenty tej książki, nie zmieniaj ich treści i koniecznie zaznacz, czyje to dzieło

Toruń 2018

ISSN 2084-3291

Współwydawcami czasopisma są Bakijski Uniwersytet Słowiański oraz Kazachski Uniwersytet Narodowy im. Al-Farabi w Ałmaty

Czasopismo jest afiliowane przy Wydziale Politologii i Studiów Międzynarodowych Uniwersytetu Mikołaja Kopernika w Toruniu

Wydawnictwo prowadzi sprzedaż wysyłkową: tel./fax 05664850 70, email: marketing@marszalek.com.pl

Wydawnictwo Adam Marszałek, ul. Lubicka 44, 87-100 Toruń

tel. 5666081 60, e-mail: info@marszalek.com.pl, www.marszalek.com.pl

Drukarnia, ul. Warszawska 54, 87-148 Łysomice, tel. 566783478 


\section{SPIS TREŚCI / CONTENTS / ОГЛАВЛЕНИЕ}

\section{ARTYKUŁY / ARTICLES / CTATbИ}

С ветл лана Черв онная, «Национальньй лидер» («отеи, народа») в европейском и азиатском восприятии (на примере вождей национального движения крымских татар)

Mich ał Lubina, Rosja Władimira Putina a Chiny Xi Jinpinga. O wpływie przywódców politycznych na politykę w państwach autorytarnych: przypadki rosyjski i chiński

Natalia A. Roślik, Przywództwo w Eurazjatyckiej Unii Gospodarczej 63

Paweł Wow ra, Uwarunkowania mocarstwowości Chin 77

Zuzanna Pierzchała, Ekonomiczny aspekt mocarstwowości Chińskiej Republiki Ludowej zuwzględnieniem jej procesu transformacji

Marek Borys, Rozwój chińskiej soft power $w$ Azji Centralnej - szanse i wyzwania

Maciej Zuziak, Konflikt na Morzu Południowochińskim. Zarys historyczny, omówienie problemów natury politycznej i prawnej ze szczególnym uwzględnieniem elementów polityki zagranicznej Chin

\section{SPRAWOZDANIA / REPORTS / OTЧETЫ}

B artos z Płotka, A Report from the Vth International Asian Congress and the XIIth International Conference - The Direction of Asia, Diversity, Dialogue on the 
100th Anniversary of Poland's Independence and Azerbaijan Independence, Torun, May 9-11, 2018

Kamila S. Kowalska, Problemy bezpieczeństwa Dalekiego Wschodu i Pacyfiku - sprawozdanie z V Międzynarodowego Kongresu Azjatyckiego, Toruń, 9-11 maja 2018 roku

Judyta Bielanowska, Sprawozdanie z konferencji „Badanie i mierzenie przywództwa politycznego", Warszawa, 12 czerwca 2018 roku

Natalia Gburzyńska, Sprawozdanie z V Międzynarodowego Kongresu Azjatyckiego, Toruń 9-11 maja 2018 r.

\section{RECENZJE / REVIEWS / РЕЦЕНЗИИ}

Wojciech Mincewicz, Postawy Polaków wobec przemocy w polityce [recenzja ksiązki Polacy wobec przemocy politycznej: studium typów postaw i ocen moralnych]

Michał Dahl, Obszar poradziecki w procesie przemian [recenzja ksią̇ki Przemiany polityczno-społeczne w przestrzeni poradzieckiej]

Kamil Pietrasik, Problemy obszaru postsowieckiego nigdy nie byly tak blisko, jak obecnie [recenzja książki Pogranicze cywilizacji. Współczesne wyzwania Azji Centralnej i Kaukazu]

Marzena Mruk, Stare i nowe kierunki polityki Chin - droga ku hegemonii? [recenzja książki Rozważania o kierunkach współczesnej polityki Chin]

Informacje dla autorów/Informations for authors / Информация для авторов .... 